\title{
Das concepções de memória e identidade de Candau à representação dos carretéis de Iberê Camargo
}

From the memory and identity conceptions of Candau to the representation of the spools of Iberê Camargo

\author{
Mirian Martins Finger*
}

\begin{abstract}
Resumo
O presente artigo abordará algumas questões referentes à relevância da memória no fazer plástico do artista gaúcho Iberê Camargo, mais especificamente na série Carretéis. Para isso, o texto será balizado em Joël Candau (2005-2014) e suas concepções alusivas à memória e identidade, assim como em Halbwachs (2006), Gagnebin (2006) e Nora (1993); além de autores que contemplam a temática "arte" (Goodman, 1978) e "Iberê Camargo", como Massi (2009), Pasta (2003), Siqueira (2009) e textos do próprio artista $(1987 ; 2009 ; 2012 a ; 2012 b)$. Há neste breve estudo uma tentativa de situar alguns momentos da vida artística de Iberê e demonstrar, por exemplo, como a "memória propriamente dita ou memória de alto nível" e a "metamemória" do artista integraram sua produção plástica. O escrito terá início com uma breve conceituação dos modos de memória de Candau, seguido por um brevíssimo relato sobre a vida do artista. A seguir, serão introduzidas as questões relevantes ao tema memória, explanando a partir da trajetória do artista, a presença da memória propriamente dita (recordações e lembranças) como mote para a produção gráfica, pictórica e textual, e a metamemória (representações que fazia de sua memória).
\end{abstract}

Palavras chave: Memória; Metamemória; Representação cultural; Iberê Camargo; Carretéis.

\begin{abstract}
This article discusses several issues concerning the importance of memory in the plastic works of the Brazilian artist Iberê Camargo, more specifically in the Spools series. For this, the text will be based on Joël Candau (2014) and his allusive concepts to memory and identity, as well as Halbwachs (2006), Gagnebin (2006) and Nora (1993); in addition to the authors that contemplate the theme "art" (Goodman, 1978) and "Iberê Camargo" such as Massi (2009), Pasta (2003), Smith (2009) and texts by Joël Candau himself $(1987 ; 2009 ; 2012 a ; 2012 b)$. In this brief study, there is an attempt to place some artistic moments of the artistic life of Iberê and demonstrate, for example, how "memory itself or high-level memory" and "metamemory" of the artist integrated his plastic production. The writing will begin with a concise conceptualization of the memory modes of Candau, followed by a very brief account of his life. Then, an introduction of the issues relevant to the topic of memory will be given, explained from the trajectory of the artist, memory presence itself (memories and recollections) as a motto for the graphic, pictorial and textual production, and metamemory (representations made in his memory).
\end{abstract}

Keywords: Memory; Metamemory; Cultural representation; Iberê Camargo; Spools.

\footnotetext{
* Doutora em Epistemologia e História da Ciência pela Universidad Nacional de Tres de Febrero Argentina. Professora da Universidade Federal de Santa Maria (UFSM).
}

Recebido em julho de 2016 | Aprovado em novembro de 2016. 


\section{Breves concepções de Memória e identidade segundo Candau}

Candau, em sua obra Memória e identidade (2014), propõe em uma perspectiva antropológica, uma classificação das revelações da memória. Sua contribuição diz respeito ao estudo das relações entre memórias individuais e memórias coletivas. Para isso, o autor classifica a concepção de memória em três níveis: a protomemória, a memória propriamente dita e a metamemória, além de opor conceitos de memórias fracas e memórias fortes. É possível afirmar que Candau reduz a dicotomia referente às concepções de memória individual e memória coletiva, afinal, ele propõe que a protomemória e a memória propriamente dita são constituídas separadamente, e desse modo não podem ser compartilhadas. Ainda que Candau não aprofunde esses conceitos nessa obra, sua exposição é suficiente por ora, pois de Memória e identidade, serão trazidos outros fragmentos para balizar o trabalho aqui proposto. Desse modo, este texto se interessa não somente pelas concepções, memória e memória propriamente dita, mas também por outros aspectos, tais como o conceito de memória fraca e memoria forte. Do mesmo modo, buscaremos aporte na obra Antropologia da memória (2005) de Candau, onde o autor discute a questão psicalítica da memória, deliberando o inconsciente como a memória do indivíduo na sua forma oculta. Nesse trabalho Candau afirma que a capacidade psicológica da memória irá derivar em cinco funções: "a aprendizagem, a memória propriamente dita, o esquecimento, a recordação e o reconhecimento." (CANDAU, 2005, p. 34). Candau sublinha a importância da abordagem psicológica para o estudo da memória e atribui a Théodulo Ribot (18391916) a biologização da memória, ou seja, a memória deixa de ser julgada como facultade da alma para ser o que Candau diz ser uma expressão de Cabanis, uma “"secreção” do cérebro.” (CANDAU, 2005, p. 33). O autor também pondera sobre as bases míticas de memória, distinguindo quatro grandes correntes. As três primeiras lidam com formas arcaicas de memória, que a consideram somente como forma de atingir o passado. Na quarta orientação busca em Aristóteles o interesse na relação entre a percepção do tempo e da memória - aqui anuncia o advento dos tempos modernos e suas representações. Candau observa ainda em Santo Agostinho três tipos de memória, "a memória dos sentidos, a memória intelectual e a memória de sentimentos" (CANDAU, 2005, p 45), mas é no presente que a imagem do passado se dá, o que faz da memória um complexo processo, que adota passagens sinuosas e incertas. 
Candau denomina de "memória propriamente dita" ou "memória de alto nível" aquela que essencialmente trata da "recordação ou reconhecimento; evocação deliberada ou inovação involuntária de lembranças autobiográficas ou pertencentes a uma memória enciclopédica (saberes, crenças, sensações, sentimentos, etc.)." (CANDAU, 2014, p 23). Afirma que a memória de alto nível está diretamente vinculada à faculdade de memória. Já a metamemória é uma representação referente à faculdade de memória. A metamémoria estaria organizada como uma memória recuperada a partir de uma admissão provocativa, o que possibilita que esta diga respeito à construção de identidade, ou seja, é a maneira que interpretamos e representamos nossas lembranças e o que fazemos com elas. E ainda, "cada um de nós tem uma ideia de sua própria memória e é capaz de discorrer sobre ela para destacar suas particularidades, seu interesse, sua profundidade ou suas lacunas." Na obra de Candau (2014) verifica-se que é a metamemória que irá referir-se à memória coletiva por ser um conjugado de representações da memória. Entretanto, o autor chama a atenção quanto à relação das representações com a memória, assim como sua capacidade de compartilhamento. Nesse sentido, Candau retoma Sperber quando este "distingue os processos intraindividuais e os processos interindividuais do pensamento e da memória, ou seja, entre as representações mentais e as representações públicas." Entende-se como intraindividual aquilo que contempla as "crenças, as intenções, as preferências" e como interindividual o que refere "os sinais, os enunciados, os textos, as imagens." Para ele, "quando uma representação mental é comunicada de um indivíduo a outro - a maior parte permanece própria a um indivíduo - ela se transforma em representação pública." (CANDAU, 2014, p. 36-37).

Ao alcançar o tema da representação pública, chega-se ao foco deste texto, visto que será tratada a presença da memória no trabalho plástico do artista gaúcho Iberê Camargo. Para o conceito de representação cultural, Candau (2014, p. 38) cita Finley: "uma representação cultural 'compreende um conjunto de representações mentais e públicas. Cada versão mental é o produto da interpretação de uma representação pública que é ela própria a expressão de uma representação mental'”. Portanto, a memória para Candau (2014), a partir de Finley, é aquela que transmite repetidamente as lembranças de um único ou alguns indivíduos, para um amplo número de pessoas. Nesse sentido, a obra de Iberê Camargo, objeto de nosso estudo, configura-se como uma representação mental que, como produto da memória propriamente dita, se modifica e se transforma em produto cultural. 


\section{Brevíssimo relato sobre vida e obra de Iberê Camargo}

Nascido em Restinga Seca, Rio Grande do Sul, em 1941, Iberê Bassani de Camargo era de origem humilde. Era filho de ferroviários e da região onde viveu a primeira fase de sua vida, pequeno vilarejo de entroncamento ferroviário e polo militar, absorveu o bucolismo, o silêncio e a tristeza característicos da campanha, o que afirma ter sido determinante em toda sua trajetória artística. A sanga, o mato a estação de trem, a arapuca armada, seu automóvel de brinquedo, foram lembranças jamais apagadas de sua memória. Lembranças que para ele "são lembranças, imagens de um livro de viagem” (CAMARGO, 2012 b, p. 11). Porém, não houve nesse ambiente nenhum tipo de estímulo artístico. Tinha como um dos hábitos preferidos mexer nas gavetas da mãe, as quais para ele guardavam muitas surpresas: retalhos de tecidos, carretéis, "coisas mutiladas". Seus primeiros traços foram feitos sentado no chão sob a mesa, ainda com quatro anos de idade (CAMARGO, 1985, p.14).

Iberê, morando com a avó Chiquinha, em Santa Maria, deu início a seus primeiros estudos em pintura no ano de 1927, na escola de Artes e Ofícios da Viação Férrea de Santa Maria. Desse período Iberê conservou um trabalho fecundo e apaixonado, chegando a produzir o maior número de trabalhos realizados pela turma. Entre desenhos a crayon e óleos chegou a receber um prêmio de cinquenta mil réis juntamente com uma promessa, jamais concretizada, de ir para o Rio de Janeiro. Apesar da decepção de seu pai, que queria vê-lo doutor, abandonou os estudos e em 1933 teve sua primeira atividade profissional como aprendiz do escritório técnico do Primeiro Batalhão Ferroviário, na cidade de Jaguari, onde logo assumiu a função de desenhista técnico.

Já em Porto Alegre, três anos depois, retomou os estudos no curso de Arquitetura do Instituto de Belas Artes e logo passou a retomar suas pesquisas pictóricas tendo a esposa como modelo. Nessa época, nas horas vagas, dividia com seu colega de trabalho, Vasco Prado, um espaço para produção artística - "desenhava tipos de rua, empregadas domésticas, num galpão de madeira que ele construíra perto de casa, tão remendado como uma maloca." (CAMARGO, 2012b, p. 19). Sua pintura explorava as temáticas da figura humana, da natureza morta e da paisagem.

Iberê fez sua primeira exposição na única galeria da cidade de Porto Alegre, Casa das Molduras. A partir de então a cidade começa a ficar acanhada para ele, pois como uma cidade conservadora ainda não tinha se permitido as influências modernistas. 
Por isso, procura Décio Soares de Souza que, juntamente com o governador do Rio Grande do Sul, consegue uma bolsa para Iberê estudar no Rio de Janeiro. Naquela cidade, Portinari aconselhou-o a não ingressar na Escola de Belas artes e procurar Guignard. Passou a relacionar-se com intelectuais e artistas como Goeldi, Maria Leontina, Djanira e Solano Trindade e cursou a Escola de Belas Artes, tendo como mestre Augusto Bracet. Os métodos acadêmicos empregados pelo professor e sua insistência em transformar uma índia Acarajá em cândida madona o fez encerrar sua carreira acadêmica. Movido pela insatisfação com os ensinamentos universitários, resolveu aceitar a indicação de Portinari e buscou Guignard para ser seu mentor particular. Em 1947, com a obra intitulada Lapa, obtém o Prêmio de Viagem a Europa.

Na Europa Iberê estudou com Giorgio De Chirico em Roma e André Lothe, em Paris, experiências que foram determinantes em sua busca pela individualidade estética. Entusiasmado e atordoado com o que tinha vivenciado nos diversos países que visitou na Europa, retornou ao Brasil em 1950 “convencido de que a única maneira de reencontrar-me era olhar com simplicidade e mundo que me cercava, com olhos de criança." (CAMARGO, 2012b, p.25). Nesse período sua produção está apoiada nos temas de naturezas-mortas e paisagens de Santa Teresa, bairro onde morava no Rio de Janeiro.

Foi a partir de 1958, impossibilitado de sair de seu ateliê no Rio de Janeiro em razão de uma hérnia de disco na coluna, o artista deu início a uma pesquisa que iria identificar o seu lugar: a série Carretéis. Esse objeto de pesquisa seria a partir de então não somente um tema, mas um motivo para seu fazer plástico. Não se caracteriza, como para a maioria dos artistas, apenas como um período onde o tema é investigado, mas como a própria identidade da trajetória do artista. Desse modo, mesmo que o artista nunca tenha retornado a residir em sua terra natal, e em termos demográficos tenha sido um migrante definitivo, seu fazer plástico nunca esteve fora de casa. Sobre esse aspecto esteve desvinculado dos movimentos de vanguarda artísticos.

Sua pintura é confundida com sua história. Sua "necessidade de memória é uma necessidade de história." (NORA, 1993, p. 14). Sua intensa maneira de sentir a vida mescla-se com sua memória, seu semblante e com os gestos marcados pela trajetória densa da tinta que cursa sua obra e registra o velho objeto revisitado. Foi dessa maneira, vistoriando e registrando seus rastros, que Iberê Camargo não permitiu que a relação de veneração com si mesmo se quebrasse e se tornasse invisível, sustentando assim, por meio de sua obra, a continuidade de sua história. Promoveu uma narrativa através da 
experiência pictórica aliada à reconstrução do passado por meio de rastros derivados de reflexões sobre a memória (GAGNEBIN, 2006). É o objeto ausente se fazendo presente por meio da lembrança e da representação plástica e que o denomina. Assim, o objeto carretel registrado na tela é o rastro do pensamento, dos fatos e da história do passado do artista. Passado presentificado pelo rastro, que mesmo morto, é significado pelo trabalho de pesquisas simbólicas e criativas que mantem viva sua memória.

$\mathrm{Na}$ visão de alguns críticos como Teixeira Leite e Pierre Courthion (apud VICENTINI; CASTILHOS; RIBEIRO, 2010, p. 100), a obra de Iberê extrapola a qualquer catalogação. Nesse sentido, pode ser comparada, por sua originalidade, ao Barroco brasileiro. Ao morrer, Iberê levou consigo o carretel objeto, o carretel brinquedo, mas deixou ao porvir a permanência de sua obra, o carretel símbolo. A obra de Iberê Camargo é reconhecida e legitimada como uma obra integrante da história da arte no Brasil, não somente por ter sido produzida por um brasileiro, mas por ser composta das memórias de infância de alguém que vivenciou um cenário tipicamente regional, como por exemplo, um pátio bucólico e uma estação ferroviária com peculiaridades locais.

\section{As concepções de memória em Caudau presentes na série Carretéis de Iberê Camargo}

A memória em Iberê configura-se em via dual; de um lado aquela memória a qual Candau (2014, p. 23) denomina "memória propriamente dita ou de alto nível", ou seja, memória existente pela recordação e pelas lembranças biográficas. Por outro lado, a "metamemória" (CANDAU, 2014, p. 23). Nesta, a memória do artista elege uma forma de interpretação na qual suas recordações e lembranças são o mote para suas representações. Por outro lado a interpretação dessas memórias, tanto pela via plástica quanto pela textual, resulta em uma produção artística reconhecida no Brasil e também fora dele. Desse modo, a representação mental é interpretada, representada e ao chegar ao fruidor é comunicada, o que a transforma em memória interindividual, em representação pública.

Por mais que sejamos incapazes de analisar ou de relatar as memórias individuais por elas alcançarem alto grau de intimidade, há em alguns casos a necessidade de compartilhamento, mesmo que sejam carregadas de traumas e sofrimento. As formas que Iberê Camargo utilizou para dar vasão a esses sentimentos 
interiorizados desde a infância foi a arte pictórica, linguagem que possibilitou o compartilhamento de suas memórias. $\mathrm{Na}$ apresentação do livro de sua autoria, Gaveta dos guardados, Massi (2009, p. 18 - grifo do autor) diz que "as memórias de Iberê, sem fugir ao registro propriamente autobiográfico, inventam uma persona: o homenpintor. [...] As reminiscências do pintor remontam às experiências mais fundas do homem; estas parecem antecipar sua longa caminhada rumo à pintura." A produção desse artista é originária de um passado com o qual nunca deixou de relacionar-se. Desde a série Carretéis, que se desdobrou em mais de vinte anos de pesquisa, a memória é tema e motivo para sua produção, por isso, não se caracteriza, como para a maioria dos artistas, apenas como um período onde a temática é investigada, mas como identificação do percurso do artista. Durante essa Série muitas foram as fases: figurativa, abstrata, simbólica, sombria ou iluminada, todas culminaram no esgotamento expressivo do objeto. Mesmo depois de a Série ter sido dada com finita, o objeto de memória, carretel, influenciou e continuou impulsionando os períodos vindouros, como ocorreram com as séries Manequins, Ciclistas e Idiotas. Paulo Pasta (2003) diz que

\footnotetext{
Para agir no presente, parece que Iberê tinha sempre de equacioná-lo com a memória, e a expressão só poderia se dar quando resgatava e atualizava esta ligação. É mais ou menos como se o presente só se constituísse nessa possibilidade de lembrar. [...] Creio não ser temerário afirmar que a pintura de Iberê começa a ganhar densidade poética com os carretéis, quando esse brinquedo da infância é evocado como personagem central das obras, quando fazer algo pessoal é recuperar o já vivido. (PASTA, 2003, p. 114-115).
}

Ao recuperar o já vivido, o sentimento ligado à identidade individual, o artista representa pela via da arte o que Candau (2014, p. 77) denomina "núcleo de sentidos", pois este está organizado por elementos do passado, mas constituídos por uma préconstrução daquilo que o artista representa "no momento da evocação." Desse modo, a anamnese de Iberê sofreu influência do presente. Para Candau (2014, p. 75), esse processo oferece "uma visão dos acontecimentos passados em parte transformada pelo presente ou, mais exatamente, pela posição que ele próprio ocupa nesse presente". Espaço que não só sugere uma representação, como também organiza uma operação simbólica entre memória e arte. Memória que alcança o tempo passado e que carrega uma realidade vivida; assim como propõe Halbwachs (2006, p. 156): “O tempo só é real na medida que tem um conteúdo, ou seja, na medida que oferece ao pensamento uma matéria de acontecimentos." Portanto, os relatos pictóricos de Iberê são originários de 
lembranças e são fenômenos que produzem efeitos de verdade, pois segundo Candau (2014, p. 72),

[...] para toda manifestação da memória há uma verdade do sujeito, diferenças recuperadas entre a narração (a memória reconstituída, as maneiras de 'ter por verdadeiro') e a realidade factual: se podemos dizer que a verdade do homem é o que ele oculta, o fato de ocultar é também sua verdade.

A verdade na representação histórica ou artística não está contida em nenhum tipo de correspondência de crenças e objetos relacionados a qualquer tipo de objetivação, o que não só dilata o lastro da interpretação histórica e artística, mas também liberta a linguagem, e a expressão artística, no que tange à representação e à verdade como correspondência. E a liberdade que Iberê exercia em sua obra plástica é coerente a sua posição em relação aos movimentos artísticos tão fertilizados em períodos de sua "formação", e dos quais não se acompadrava. Era homem atento aos acontecimentos e demonstrava preocupação com os nortes da arte de sua época. Porém, a concomitância do movimento abstracionista ${ }^{1}$ e das Bienais de São Paulo no Brasil da década de cinquenta, colocavam em ebulição os paradigmas artísticos, mas não alteravam suas convicções em relação a sua produção. Criticava essa modernização da arte com certa rabugice e seguia seu trabalho no silêncio de suas crenças. Sua fé estava contida no exercício de um processo de metamemorial e afirmava que a verdade do artista está na intuição (CAMARGO, 1985, p. 43). Na temporalidade da vida e da arte está a metáfora do uníssono, em que a primeira guarda a memória e a segunda conserva a fisionomia de cada época, é atemporal. Afirma que, em seus "quadros, o ontem se faz presente no agora" (CAMARGO, 2009, p. 31). Assim, o artista busca em suas memórias uma maneira de lidar com o tempo. Diz que

Seria interessante se eu pudesse unir, no agora, o passado e o presente, tudo. Porque, na verdade, nós sempre perdemos, o passado fica para trás, é sucata, é coisa modificada, destruída, apodrecida - isso é o passado. E nós estamos no presente, e na frente há sempre uma luz, nós sempre estamos caminhando [...] Agora, eu não sei, começa a aparecer nos meus quadros essa coisa [...] esses fantasmas, o meu passado. Cessa o tempo, acaba. Não há mais passado, presente e futuro. Só o tempo, único. É muito estranho. (COTRIM, 1992, p. 107-23).

\footnotetext{
${ }^{1}$ Movimento artístico atribuído inicialmente à produção do russo Wassily Kandinsky (1866-1944), por volta de 1910 e que abandona a concepção de arte como imitação da natureza, buscando interpretá-la por meio de formas alheias ao seu reconhecimento imediato (CHILVRES, 1996).
} 
Um tempo retido na lembrança que refere somente aos acontecimentos que ali ocorreram (HALBWACHS, 2006) e que de certa forma está presente a alteridade da lembrança, ou seja, ao passado da lembrança está agregado o futuro dessa lembrança. Porém, é lembrança de um transporte de pensamento que está fora do espaço, "pois ao contrário é justamente a imagem do espaço que, em função de sua estabilidade, nos dá a ilusão de não mudar pelo tempo afora que podemos encontrar o passado no presente [...]" (HALBWACHS, 2006, p. 189). Passado que Iberê representa pictoricamente e que o coloca não somente como agenciador de um processo metamemorial, mas também como agenciador do presente.

A série Carretéis, tema explorado intensamente, como único protagonista durante longo tempo, é exemplo daquilo que Candau $(2014,72)$ chama de "passado útil”. E para o artista esse motivo, uma vez rememorado, nunca deixou de fazer parte de seu repertório pictórico, pois nele estava explícita sua busca pelos objetos afetivos guardados da infância. Os carretéis derivam de um passado "onde há boas razões para não se mover" (CANDAU, 2014, p. 72) e aparecem para o artista de maneira não verbalizada, cujo recurso utilizado para sua representação narrativa e identitária é a arte, pois, ainda que o passado não possa ser totalmente rememorado, esse é contado de maneira narrativa. O que é possível comparar com a concepção ricoeuriana de narrativa de identidade. Mas no sentido poético da narrativa histórica, em que o artista apresenta sua história de infância descrevendo o objeto carretel por meio da pintura. Pintura como possibilidade de uma "'referência não descritiva ao mundo" (GAGNEBIN, 2006, p. 42). O tempo revisitado é articulado de maneira narrativa, que, segundo Anderson (apud CANDAU, 2014, p 70), é uma narrativa de identidade como forma de "apresentação de si que terá a forma de uma "totalidade significante"”.

Ao dar sentido as memórias de infância, ou seja, ao representá-las, o artista dá sentido aos encadeamentos de sua vida quando criança. Desse modo, Candau (2005, p. 167) denomina de "ilusão biográfica", pois dá sentido a acontecimentos pessoais que, ao inventariá-los, de certa maneira ordena-os e torna-os coesos aos eventos passados e que de tão significativos podem ser conferidos ao momento vivido. Na concepção de Candau, a "ilusão biográfica" tem essa capacidade porque ao emanar 
[...] a memória autobiográfica visa construir um mundo relativamente estável, verossímil e previsível, em que os projetos de vida assumem sentido e onde a sucessão dos episódios biográficos perde o seu caráter aleatório e desordenado para integrar num continuum tão lógico quanto possível cujo ponto de origem a ponto de destino são constituídos pelo próprio sujeito, ou, eventualmente, pela sua família (as raízes), o seu clã, o seu país (os mitos fundadores). (CANDAU, 2005, p. 168 - itálico no original).

De uma forma mais elaborada na memória está contida uma narrativa que agrega passado e presente. É uma representação derivada de uma transição entre o já vivido e o contemporâneo, mas que avista um horizonte de expectativa para o futuro, o que a configura como uma "memória viva". (CANDAU, 2005, p. 168). Iberê agrega no presente o passado por meio da "memória viva" e projeta-se para o vindouro. Isso fica explicitado em um dos esboços autobiográficos que fazem parte de seu repertório de motivos para a produção artística.

Restinga Seca era para mim a estação da Viação Férrea do Estado, a caixa d'água; a sanga; o rancho da Rua, minha ama; o Ipo, que me trazia escanchado ao pescoço, cavalgando; a arapuca armada na moita à espreita do pássaro; o meu automóvel de brinquedo esquecido no oitão da estação sobre a pilha de postes de ferro; o doutor Valentim, negro retinto e pachola, permanentemente bêbado, a enticar na hora do trem com a negra Egalantina, empregada de minha mãe, com este estribilho: "No céu não luzem estrelas pretas'; ainda o buraco fundo com seus ninhos de caturritas; o moço de culotes brancos descendo afoito o precipício para impressionar as moças; a Célia, que desenhou para mim um grande peixe colorido; a menina nua, chorando, encostada à parede; a Chata, irmã de criação, e as nossas maldades. E longo, longe, longe, meu pai e minha mãe andando pequenininhos, no caminho do cerro. São lembranças, imagens de um livro de viagem. (CAMARGO, 2012, p. 11).

Um livro do passado que fará parte das viagens do presente e futuro, pois entre suas narrativas verbais e textuais sempre deixou claro que está preocupado em preserválas. "Essas figuras que ora povoam meus quadros (elas mesmas são os quadros) nascem da minha saga, da vida que dói." (CAMARO, 2012, p. 26). Percebemos a relação dessas narrativas com seus quadros quando temos acesso a elas. No entanto, pode haver nesse universo relatado uma construção imaginada, sonhada que beira a ilusão, ou seja, a “ilusão autobiográfica". Iberê evidencia essa imaginação fertilizada pelo passado em passagem como "Sou um andante. Carrego comigo o fardo de meu passado. Minha bagagem são meus sonhos. [...]. Realidade e miragem se confundem. Os quadros que pinto são visões que breve serão os fósseis semeados à margem de meu rastro" (CAMARGO, 1994, p. 54). A "ilusão biográfica" como narrativa de vida da qual nos fala Candau pode muitas vezes ter movimentos cambiantes e provisórios, do mesmo 
modo que pode ser "inventada". Nesse sentido, é a memória propriamente dita que, recuperada, é "inventada" e representada, ou seja, é a metamemória.

Outro modo utilitário ao nosso estudo, talvez mais metafórico do que análogo, é a concepção de "representação factual" de Candau (2014, p. 39) - "aquelas relativas à existência de certos fatos" - para fazer uma comparação com a análise que Iberê Camargo fazia sobre suas referências carretelianas, ou seja, a memória do objeto propriamente dito, factual. Para ele não era concebida a ideia nem por um momento, que sua obra tivesse abandonado a figuração. Como legatário de Picasso, defendia que "até a forma mais abstrata é Figura" (SIQUEIRA, 2009, p. 88). Partia sempre da figura e se o resultado alcançado transfigurasse numa abstração, era pelo insistente processo de busca pela forma, pela síntese do objeto estudado, mas não por um ideal de afastamento da realidade. Por outro lado, mais uma vez utilizando a comparação, tomemos o conceito de Candau (2014, p. 39) de "representação semântica" - "as representações relativas ao sentido atribuído a esses mesmos fatos" - o sentido dado ao carretel, por mais que perdesse sua figuração, continuava sendo um carretel, porém agora ganhava títulos como Símbolos, Signo, Desdobramento, Andamento, Jogo, Vórtice, impetrando-se assim como símbolo, como totalidade significante. Mas a metamemória simbólica nessas fases vai remeter ao objeto carretel, ora brinquedo, talvez um violão, um dado, um guerreiro, um pião ou uma pandorga, ora utensílio prático do coser materno. Para Halbwachs (2006), são objetos que

\footnotetext{
[...] não falam, mas nós os compreendemos, porque têm um sentido que familiarmente deciframos. São imóveis somente na aparência, pois as preferências e hábitos sociais se transformam e, quando nos cansamos de um móvel ou de um quarto, é como se os próprios objetos envelhecessem. (HALBWACHS, 2006, p. 158).
}

Entretanto, o cansaço do velho objeto, marcado pela história da infância, ao ser memorado, interpretado e representado, transforma-se num novo objeto, um objeto imagético pertencente à metamemória. E no modo de representação do artista, os velhos carretéis são oriundos de um pátio real, íntimo e reminiscente da infância, mas que depois de reconhecidos alcançam a interindividualidade. "Estão girando enfiados nas máquinas de costura, despindo-se do fio. Estão sobre o convés capitaneando navios que singram sangas. Estão rodopiando nas piorras.” (CAMARGO, 1998, p. 99). É objeto derivado da memória que se transforma ao travestir-se de guerreiro para um 
[...] combate dos Pica-Paus e dos Maragatos que primo Nande e eu travávamos no pátio. Eles estão impregnados de lembranças. Pelas estruturas de carretéis, cheguei ao que se chama, no dicionário da pintura, arte abstrata. Neste período, o ritmo é gestual, porém dirigido, não mera impressão de um gesto qualquer (CAMARGO, 2012, p. 25).

O movimento da memória, "aberta à dialética da lembrança" (NORA, 1993, p. 9) é suscetível ao artista que se questiona sobre o que aconteceu com estes objetos, os carretéis da infância: "Faz tanto tempo que nos separamos. Eles devem ter morrido soterrados nos quintais e nos porões das velhas casas." (CAMARGO, 1998, p. 99). Entretanto, permanecem na memória e vão sendo reconstruídos, reinventados; o que antes era objeto real revestido de formas estanques torna-se um ser pictórico feito com formas movediças, gestos drásticos, cores esculpidas em matéria densa. E dessa forma, Iberê busca nas lembranças, instalada pela memória, enraizar o objeto "carretel".

É possível, sobre os três modelos de memória citados por Candau (2005) e dados por Santo Agostinho, acomodar o trabalho de memorização que Iberê fez ao construir a série Carretéis. Da primeira, a memória dos sentidos, o artista evocou a forma, o movimento, a cor, a textura e a luminosidade compreendidos no plano plástico. Da segunda, a memória intelectual, foi subtraída a experiência, os conhecimentos adquiridos ao longo de sua trajetória e que influenciaram sua obra. E do último tipo de memória, a dos sentimentos, o artista capturou os prazeres, as tristezas, os desejos e frustrações presentes tanto na infância quanto nos momentos da recordação.

O carretel como brinquedo rememorado como personagem de batalhas lúdicas travadas com o primo talvez não sejam preservadas por este ente familiar. Para Caundau (2014, p. 34), "toda tentativa de descrever a memória comum a todos os membros de um grupo a partir de suas lembranças, em um dado momento de suas vidas, é reducionista, pois ela deixa na sobra aquilo que não é compartilhado". Assim, Halbwachs (2016), ao discorrer sobre as memórias individuais e coletivas, diz que pessoas que amamos, com os mesmo interesses, são muitas vezes envolvidas em nossas lembranças de maneira totalmente estranha a elas. No entanto, a lembrança é para nós explicada "pelo que estava no centro de nossa vida afetiva ou intelectual [...] porque aos nossos olhos ela se resume em uma sequência de impressões que somente nós conhecemos." (HALBWACHS, 2016, p. 50). A lembrança do objeto carretel ao ser representado recupera não só o objeto com suas transfigurações, mas também a própria realidade do artista. A intimidade da interpretação que Iberê dá aos carretéis distancia-se de qualquer tentativa de representação similar ao objeto, mas familiariza-se cada vez 
mais com seu modo de criar uma nova versão plástica do objeto. Os carretéis, no entanto, não despontaram da infância do artista exclusivamente com a intenção de representá-la, mas de dar prosseguimento àquela simbolização iniciada no pátio da casa onde vivia. Para ele não há divisão entre o carretel e a pintura, entre a vida e a arte. Estão contidos no carretel, de maneira indissociável, a forma e o conteúdo do objeto, onde esse é muito mais que um simples pretexto. Eles são os "brinquedos" que viajam no tempo e "tornam-se míticos personagens de uma saga de fantasmagóricas visões." (CAMARGO, 1985, p. 22). O artista proclama que é "Símbolo, signo, personagem - o carretel -, brinquedo da minha infância e agora, nesta fase, tema da minha obra, está impregnado dos conteúdos do meu mundo.” (CAMARGO, 1998, p. 99). Lembranças que, apesar de alcançarem um passado, a princípio poderiam ser consideradas como "memória fraca" (CANDAU, 2014, p. 44-45) por não serem compartilhadas "por um conjunto de indivíduos cuja identidade coletiva é, por esse mesmo fato, relativamente inatingível". Para Candau (2014), a mobilização da memória é a sua transmissão, é a expansão da memória que tem o papel de "“fixar"” o passado.

\footnotetext{
(lugares, escritos, comemorações, monumentos, etc.) contribuem para a manutenção e transmissão da lembrança de dados factuais: estamos, assim, em presença de "passados formalizados", que vão limitar as possibilidades de interpretação do passado e que, por essa razão, podem ser constituídos de uma memória "educada", ou mesmo, "institucional", e, portanto, compartilhada. (CANDAU, 2014, p. 118).
}

Sobre esta esfera, o lugar que guarda o maior acervo de Iberê, a Fundação Iberê Camargo contribui não só pra a preservação, mas também para a transmissão da memória do artista. $\mathrm{O}$ artista ao transmitir sua memória do carretel nas brincadeiras de infância, por meio da obra artística, "fixa" seu passado e não o deixa apenas como um legado, mas deixa o registro de sua identidade, de como ocupou um lugar no mundo e também de como o representou. Para isso, o artista utilizava o que Candau denomina "metamemória". A representação que o artista faz de suas memórias configura-se na história da arte no Brasil como uma arte vinculada a uma poética informal que se caracteriza por sua originalidade. Sua trajetória artística se estabelece estudando os grandes mestres e por essa razão se localiza em meio a condições adversas, pois os padrões estéticos no país se encontravam contaminados por movimentos modernistas ocorridos na Europa que despontavam no país com novos paradigmas conceituais e modismos postulados. Como afirma Mammi (2003), se referindo ao contexto de Iberê, “num país que não tinha história, mas apenas memória, era justamente na memória 
individual que era preciso afundar para encontrar elementos de linguagem análogos, mas não coincidentes, àqueles que artistas europeus estavam forjando dentro ou contra a História" (MAMMI, 2003, p. 151-152). E sobre esse âmbito, a memória do carretel, objeto das brincadeiras de infância, torna-se o agente para a construção de uma obra que se estabeleceu como algo nunca visto na arte no Brasil. Apesar de se caracterizar como exposição de uma intimidade muito particular, a série Carretéis é a própria arte de vanguarda defendida pelo cenário artístico brasileiro da época e tão desprezada por Iberê. Afinal, a singeleza de um objeto industrial com sua função de desenrolar fios, ao ser revisitado pela memória, transforma-se em uma obra construída a partir da aliança entre tradição e ineditismo. Ineditismo este, não somente pelo objeto carretel como motivo, mas também pela maneira original que foi explorado pictoricamente, por isso de vanguarda.

A representação dessa memória ao ser fruída e integrada à história da arte no Brasil passa a ser "memória forte", "massiva, coerente, compacta e profunda, que se impõe a uma grande maioria dos membros de um grupo, qualquer que seja seu tamanho, sabendo que a possibilidade de encontrar tal memória é maior quando o grupo é menor." Desse modo, não somente a memória está envolvida nesse processo de transmissão, mas também a metamemória, pois como representação da memória, fornece a grupos de artistas, de estetas, de historiadores, de críticos de arte, curadores e apreciadores em geral, uma identidade compartilhada. De certa forma, é uma maneira da memória cumprir o papel de "mãe da história" (CANDAU, 2014, p. 133). O carretel da memória do artista ao ser interpretado, representado e fruído passa a ser história, passa a se relacionar com o tempo vivido por Iberê e com sua relação com as coisas do mundo e, assim, história que "pertence a todos e a ninguém, o que lhe dá uma vocação para o universal" (NORA, 1993, p. 9). E mesmo que para Nora (1993, p. 9) "a memória é sempre suspeita para a história, cuja verdadeira missão é destruí-la e repetir”, o resultado do trabalho de Iberê é reconhecido, e ao ser legitimado se reconstrói através do poder de abrir-se à análise do discurso; papel da arte, papel da história.

\section{Considerações finais}

Este texto teve a intenção de abordar o tema memória na produção da Série Carreteis de Iberê Camargo a partir das obras de Joël Candau, Antropologia da memória (2005) e Memória e identidade (2014) e de outros autores que abrigam o 
tema. Como vimos, a memória de Iberê Camargo foi determinante em seu fazer artístico, pois foi nela que o artista abriu brechas entre o passado e o presente e encontrou o sentimento do antes e do depois (NORA, 1993). O seu trabalho percorreu diversos momentos de memória de infância, porém foi na lembrança dos carretéis, objeto transformado em brinquedo, que o tempo passado foi revisitado. Desse modo, como agenciador de uma norma íntima, por meio de lembranças pessoais, o artista passou a ser agenciador de uma norma cultural. Isto é, suas memórias do passado articuladas ao seu tempo presente são representadas plasticamente, e ao serem legitimadas como obra de arte, integrantes da história da arte no Brasil, passam a fazer parte de uma memória cristalizada, de uma memória coletiva. Por conseguinte, seu trabalho movido por uma memória representada passa a ser autenticado por uma realidade existente nos atos de memória coletiva presente em museus e, principalmente, na Fundação Iberê Camargo, lugar de memória (NORA, 1993), que leva seu nome e abriga maior parte de sua produção artística. Lugar este de continuidade da memória de Iberê Camargo, lugar de memória coletiva e lugar de história. 


\section{REFERÊNCIAS}

CAMARGO, Iberê. Entrevista. In: COCCHIARALE, Fernando; GEIGER, Ana Bella. Abstracionismo geométrico e informal. A vanguarda brasileira nos anos cinquenta. Rio de Janeiro: Funarte/Instituto Nacional de Artes Plásticas, 1987.

CAMARGO, Iberê; MASSI, Augusto (Org.). Gaveta dos guardados. São Paulo: Cosac \& Naify, 2009.

CAMARGO, Iberê. In: BERG, Evelyn et al. Iberê Camargo. Rio de Janeiro: FUNARTE, Instituto Nacional de Artes Plásticas/MARGS, 1985.

CAMARGO, Iberê. No andar do tempo. São Paulo: Cosac Naify, 2012a.

CAMARGO, Iberê. No tempo. Porto Alegre: Fundação Iberê Camargo, 2012b.

CANDAU, Joël. Antropologia da memória; tradução Miriam Lopes. Lisboa: Instituto Piaget, 2005.

CANDAU, Joël. Memória e identidade. Trad. Maria Leticia Ferreira. 1. ed. São Paulo: Contexto, 2014.

COTRIM, Cecília. A paixão pela pintura - depoimento de Iberê Camargo a Cecília Cotrim Martins. Novos estudos Cebrap, São Paulo, n. 34, p. 107-123, nov. 1992.

GAGNEBIN, Jean Marie. Verdade e memória do passado. In: GAGNEBIN, Jeanne Marie. Lembrar escrever esquecer. São Paulo: Ed. 34, 2006. p. 39-48.

GOODMAN, Nelson. Ways of worldmaking. Indianapolis: Hackett Publishing, 1978.

HALBWACHS, Maurice. A memória coletiva. Trad. Beatriz Sisou. São Paulo: Centauro, 2006.

MAMMI, Lorenzo. Iberê Camargo e a pintura europeia do pós-guerra. In SALZSTEIN, Sônia. Diálogos com Iberê Camargo. São Paulo: Cosac \& Naify, 2003.

MASSI, Augusto. Carretéis da memória. In: CAMARGO, Iberê; MASSI, Augusto (Org.). Gaveta dos guardados. São Paulo: Cosac \& Naify, 2009.

NORA, Pierre. Entre memória e história: a problemática dos lugares. Projeto História, São Paulo, n. 10, p. 7-28, dez. 1993.

PASTA, Paulo. Memória e matéria na pintura de Iberê Camargo. In: SALZSTEIN, Sonia. Diálogos com Iberê Camargo. São Paulo: Cosac \& Naify, 2003.

SIQUEIRA, Vera Beatriz. Iberê Camargo: origem e destino. São Paulo: Cosac Naify, 2009.

VICENTINI, Daniela; CASTILHOS, Laura; RIBEIRO, Paulo. Tríptico para Iberê. São Paulo: Cosac Naify, 2010. 